\title{
Desalination and removal of organic pollutants using electrobiochemical reactor
}

\author{
P. Jegathambal ${ }^{1}$ R. R. Nisha ${ }^{1} \cdot$ K. Parameswari ${ }^{1}$ - M. S. P. Subathra ${ }^{1}$
}

Received: 8 June 2018 / Accepted: 16 May 2019 / Published online: 25 May 2019

(c) The Author(s) 2019

\begin{abstract}
Electrobiochemical reactor is one of the energy sustainable technologies for desalination which simultaneously treats waste water by microorganisms that are used as the catalyst for removal of salts and energy production. The microbial-induced electrochemical reaction occurring during the process and the energy produced in the reactor induce desalination. The reactor used in this study consists of 3 chambers: anode, middle and cathode which are separated using the ion exchange membranes. In this study, an air cathode with two different catholytes was used and comparative studies were carried out. The use of acidic water in the cathode chamber showed more efficiency than the phosphate-buffered solution. There were maximum removal of $60 \%$ electrical conductivity and $100 \%$ hardness during treatment. The maximum current of $1 \mathrm{~mA}$ and voltage of $850 \mathrm{mV}$ were generated using this reactor. Apart from this, there is a reduction in 45\% BOD removal in the anode chamber. The maximum power density and current density obtained were $251.8 \mathrm{~mW} / \mathrm{m}^{2}$ and $296.29 \mathrm{~mA} / \mathrm{m}^{2}$, respectively. The characterization of the deposited sludge on the membranes during the reaction was performed using scanning electron microscopy, X-ray diffraction, Fourier transform infrared spectroscopy.
\end{abstract}

Keywords Electrobiochemical reactor $\cdot$ Desalination $\cdot$ Membrane $\cdot$ SEM

\section{Introduction}

Water scarcity is the major problem faced by every continent. A few studies show that around 1.2 billion people live in water scarce areas and 500 million people are approaching this situation (United Nations Department of Economics and Social Affairs 2003). Countries like India, Kenya, Yemen, Crimea and others face severe water shortage (Glass 2010; Marshall 2011; Prakash et al. 2013; Tänzler et al. 2011). Only $3 \%$ of water is fresh and remaining $97 \%$ is found in ocean and sea as salt water. This uneven distribution and global water shortage have necessitated the requirement for desalination (Lattemann et al. 2010; Greenlee et al. 2009). Most of the current desalination technologies are energy-intensive (Carter 2013; IREA 2012; World Bank 2012; Garud et al. 2011; Elimelech and Phillip 2011; Semiat 2008). Though there are many studies carried out

P. Jegathambal

esther.jegatha2011@gmail.com

1 Karunya Institute of Technology and Sciences, Coimbatore 641114, India in minimizing the energy consumption, still it remains as a challenge (Zhang 2012).

It is estimated that in the next 20 years the average per capita supply of clean water will decrease by one-third. Desalination is one option for producing potable water from brackish water and seawater in many parts of the world, but most water desalination technologies are energy- and capital-intensive. The main desalination technologies currently used are reverse osmosis, electrodialysis and distillation. Continual improvements in desalination processes, particularly in the past decade, have made these systems more reliable and have reduced capital costs, but high energy requirements remain a concern in many parts of the world. Increasing attention is being placed on developing desalination processes powered by renewable energy, such as solarand wind-driven electricity (Zhang 2012). New membrane systems are also being developed that reduce the need for high water pressure through the use of forward osmosis. All of these systems, however, require heat sources or electrical energy input. Reverse osmosis units require a minimum of $3-5 \mathrm{kWh} / \mathrm{m}^{3}$ for water desalination (Figs. 1 and 2).

Bioelectrochemical systems (BESs) represent an array of processes capable of converting the chemical energy 


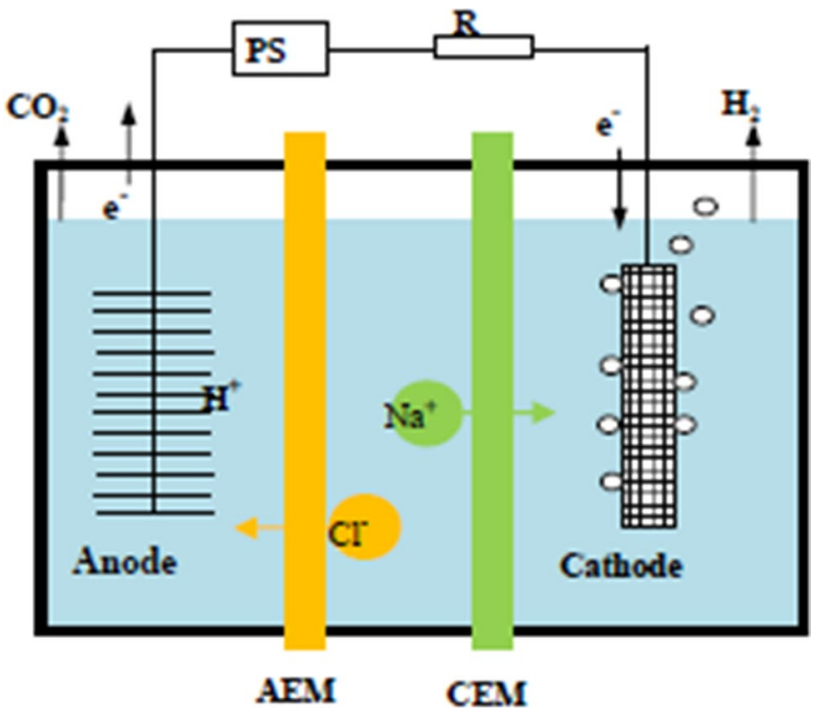

Fig. 1 Microbial desalination cell (Luo et al. 2010)

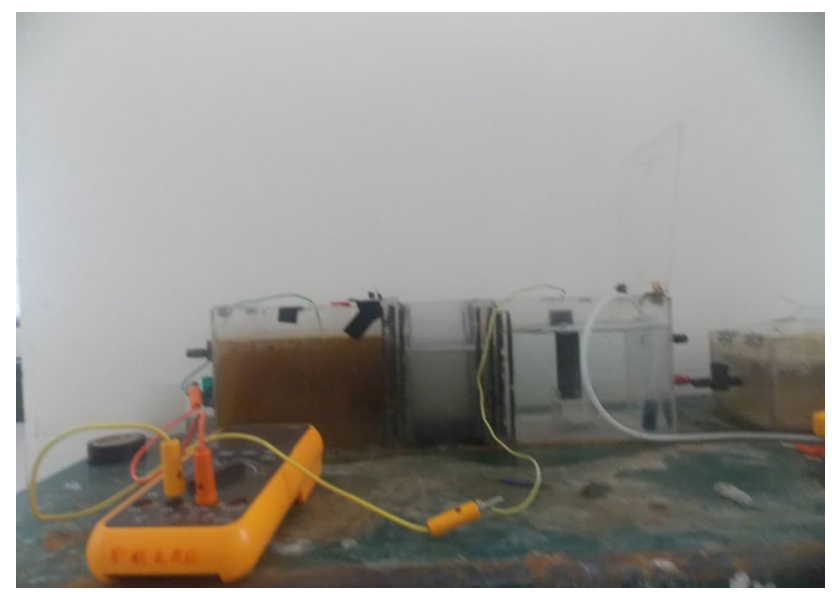

Fig. 2 Laboratory setup of microbial desalination cell

embedded in biodegradable materials including wastewater and sediments into direct electricity. BES is a new bioelectrochemical process that offers simultaneous water desalination, renewable energy production and wastewater treatment. A new technology for seawater desalination was recently developed on the basis of microbial fuel cell (MFC), called microbial desalination cell (MDC). The working principle of MDC is on the basis of a phenomenon that ion transport is needed to maintain charge balance in the anode and cathode of MFCs. The main difference of MDC compared with MFC is that MDC contains an additional desalination chamber between anode and cathode chambers separated, respectively, by AEM and CEM. In a typical three-chambered MDC system (Fig. 5), when electrochemically active bacteria oxidize organic matters and transfer electrons to the external circuit, protons are released into solution and accumulated in the anode, the AEM deposited in the anode side prevents positively charged species from leaving the anode, and thus, negatively charged species move from the middle chamber to the anode to maintain charge balance. In the cathode chamber, protons are consumed to form water with electrons, resulting in the movement of positively charged species from the middle chamber to the cathode chamber. In such way, the salt ionic species are removed from the middle chamber resulting in water desalination.

The desalination using electrobiochemical reactor (EBCR) is a new technology which treats the salt water in an energy-efficient way (Ren and Luo 2010; Kim and Logan 2013). It is designed by modifying microbial fuel cell by including an additional chamber in the middle (Mehanna et al. 2010). It usually consists of three chambers: anode, middle and cathode, separated using ion exchange membranes (Kim and Logan 2013; Mehanna et al. 2010; Cao et al. 2009; Luo et al. 2012a). In EBCR, exoelectrogeneous bacteria oxidize organic matter present in the wastewater in anode chamber and release electrons to the anode electrode and protons to the water (Mehanna et al. 2010). Anion exchange membrane which is provided between anode and middle chambers prevents the movement of protons from anode chamber. The charge carried by the protons is balanced by anions $\left(\mathrm{Cl}^{-}\right)$separated from the desalination chamber into the anode chamber.

In the cathode chamber, protons released from catholyte combine with electrons and oxygen to form water. The electrical neutrality occurs with charge balanced by cations $\left(\mathrm{Na}^{+}\right)$separated from the desalination chamber. The reactions occurring in the anode and cathode chamber are given below:

$$
\begin{gathered}
\text { Anode Chamber } \\
\mathrm{C}_{6} \mathrm{H}_{12} \mathrm{O}_{6}+4 \mathrm{H}_{2} \mathrm{O} \rightarrow 6 \mathrm{HCO}_{3}+3 \mathrm{OH}+24 \mathrm{e}^{-} \\
\text {Cathode chamber } \\
4 \mathrm{H}^{+}+4 \mathrm{e}^{-}+\mathrm{O}_{2} \rightarrow 2 \mathrm{H}_{2} \mathrm{O} \text { (Sabat et al. 2013) }
\end{gathered}
$$

Based on the factors such as stability, conductivity, biocompatibility, strength and resistivity, the selection of the electrodes is being done. The large surface area of the anode facilitates the effective growth of bacteria responsible for degradation. The electrode modified with catalysts in the cathode chamber increases the rate of oxygen reduction. Generally, the cathode and anode may of the same material. The commonly used materials are carbon brush, graphite rod, carbon paper, etc. In few studies, ferricyanide has been used as catholyte. In this study, graphite electrode was positioned as an anode and air cathode in cathode chamber. To reduce the internal resistance and increase the power generation, membranes are used. In addition, the solutions in the anodic and cathodic compartments are to be replaced several times over a cycle, resulting in less 
efficiency (Mehanna and Logan 2010). Advanced studies using stacked model, series of stacked model, series of EBCR, upflow EBCR and algae-mediated microbial cell have been carried out by researchers (Kim and Logan 2011; Zhang and He 2012; Kokabian and Gude 2012; Qu et al. 2013). EBCRs are also used for softening the water and for removing the heavy metals also (Brastad and He 2013). EBCR proves to be more efficient than MFC in energy production and waste water treatment (Luo et al. 2012b). But the $\mathrm{pH}$ imbalance is the major problem faced by EBCR. The recirculation of anode and cathode is a favorable solution for this problem (Qu et al. 2012). Biofouling and scaling of membrane reduce the efficiency of EBCR (Brastad and He 2013; Ping et al. 2013). By applying external voltage, hydrogen gas can be released from the cathode chamber (Ren and Luo 2010).

\section{Materials and methods}

\section{Reactor design}

The EBCR used in this study is a three-chambered bioelectrochemical reactor. It has three chambers like anode chamber, middle chamber and cathode chamber. The anode and middle chambers were separated using an anion exchange membrane (AEM; AMI-7001, Membrane International, Inc., NJ, USA), and the cathode chamber and the middle chamber were separated using a cation exchange membrane (CEM; CMI-7000, Membrane International, Inc.). The membranes were preconditioned by emersion in $5 \% \mathrm{NaCl}$ solution at $40{ }^{\circ} \mathrm{C}$ for $24 \mathrm{~h}$ for membrane expansion and hydration. Graphite rods of $5 \mathrm{~cm}$ diameter and $10 \mathrm{~cm}$ height were inserted into the anode and cathode chamber as the anode electrode and cathode electrode, respectively. Each chamber was designed with a volume of $3375 \mathrm{~cm}^{3}$. The liquid volumes in all the chambers were kept approximately at $3000 \mathrm{ml}$. The electrodes were connected using electric wire using a closed circuit with a multimeter.

\section{Operating conditions}

In the anode chamber, sodium acetate was added to ensure an adequate electron supply to drive. About $3 \mathrm{~g}$ of $\mathrm{NaCl}, 0.5 \mathrm{~g}$ of $\mathrm{MgSO}_{4}, 0.015 \mathrm{~g}$ of $\mathrm{CaCl}_{2}, 0.02 \mathrm{~g}$ and $0.53 \mathrm{~g}$ of vitamins and glucose were added as nutrients for the active growth of microorganisms responsible for degradation of organic matter. About $50 \mathrm{mM}$ phosphatebuffered solution (PBS) was added to maintain $\mathrm{pH}$ and to increase the alkalinity. The aerobic sludge from aeration tank of wastewater treatment plant was inoculated into the anode chamber as a seed for acclimatization process. The anode chamber was maintained in anaerobic condition to get more efficiency. The anolyte was replaced with fresh waste water after $24 \mathrm{~h}$ in the first cycle, whereas it was replaced after $12 \mathrm{~h}$ in the second cycle. In the first operation cycle, $50 \mathrm{mM}$ phosphate-buffered solution $(8.5 \mathrm{~g}$ of $\mathrm{KH}_{2} \mathrm{PO}_{4}, 21.75 \mathrm{~g}$ of $\mathrm{K}_{2} \mathrm{HPO}_{4}, 33.5 \mathrm{~g}$ of $\mathrm{Na}_{2} \mathrm{HPO}_{4} \cdot 7 \mathrm{H}_{2} \mathrm{O}$, $1.7 \mathrm{~g}$ of $\mathrm{NH}_{4} \mathrm{Cl}$ ) with conductivity $12 \mathrm{mS} / \mathrm{cm}$ and $\mathrm{pH} 7.2$ was used as a terminal electron acceptor catholyte. In the second cycle, acidic water of $\mathrm{pH} 1$ prepared by adding sulfuric acid to tap water was used. Air cathode was used in this reactor. The solution in the cathode chamber was continuously aerated to provide dissolved oxygen. The seawater sample from Nagapatinam, Tamil Nadu, and Calicut, Kerala, was kept in the middle chamber for treatment. The reactor was operated at room temperature $\left(31^{\circ} \mathrm{C}\right)$. All the solutions were replaced once the voltage generation was less than $40 \mathrm{mV}$.

\section{Performance of EBCR based on analysis of parameters}

The power generation is determined by the potential between the anode and cathode which is one of the important parameters responsible for movement of electrons. The anode and cathode potentials determine the generation of theoretical maximum voltage generated by EBCR. The overall calculations depend on the electrochemical reactions that occur in between the low potential anode (electron donor, i.e., substrate) and high potential cathode (electron acceptor). The parameters such as working voltage on the external resistance are monitored by multimeters, voltage meters and data acquisition systems. Based on the measured parameters, the current generated is calculated by Ohm's law and the energy efficiency $(\varepsilon)$ is another important parameter for evaluating how efficient of MFC compared with more traditional techniques such as anaerobic digestion. The systematic energy efficiency is calculated as the ratio of power actually produced EBCR to the heat energy obtained by substrate combustion. Electrode potential (V) $E=\mathrm{Eo}-\mathrm{RT} /(\mathrm{nF})$ $\ln \left(a_{\text {red }} / a_{\text {oxy }}\right)^{a}$; current (A) $I=E / R, E$ is voltage, $R$ is external resistance $(\Omega)$; power (W) $P=E^{2} / R$ or $P=I E$; current density $\left(\mathrm{A} / \mathrm{m}^{2}\right) I_{\mathrm{A}}=I / A, A$ is projected electrode surface area $\left(\mathrm{m}^{2}\right)$; power density (surface area) $\left(\mathrm{W} / \mathrm{m}^{2}\right) P_{\mathrm{A}}=E^{2} / R / A$; volumetric power density $\left(\mathrm{W} / \mathrm{m}^{3}\right) P_{\mathrm{A}}=E^{2} / R / v, v$ is the reactor volume $\left(\mathrm{m}^{3}\right)$.

\section{Characterization studies using XRD, SEM and FTIR}

$\mathrm{XRD}$ is a nondestructive technique to identify atomic arrangement in crystalline phases, phase composition, structural properties like lattice parameters $\left(10^{-4} \AA\right)$, grain size, thickness of thin films and multi-layers. By X-ray diffraction, the atomic planes of a crystal cause an incident beam 
of X-rays to interfere with one another as they leave the crystal. Although Bragg's law $(n \lambda=2 d \sin \theta$; the variable ' $d$ ' is the distance between atomic layers in a crystal, and the variable lambda ' $\lambda$ ' is the wavelength of the incident X-ray beam; ' $n$ ' is an integer) was used to explain the interference pattern of X-rays scattered by crystals, diffraction has been developed to measure the average spacing between layers or rows of atoms, determine the orientation of a single crystal or grain, find the crystal structure of an unknown material and measure the size, shape and internal stress of small crystalline regions.

A scanning electron microscope (SEM) is a type of electron microscope that produces images of a sample with resolution better than $1 \mathrm{~nm}$, by scanning it with a focused beam of electrons. The electrons interact with atoms in the sample, producing various signals, containing information about the sample's surface topography and composition. The number of secondary electrons emitted is a function of the angle between the surface and the beam. On a flat surface, the plume of secondary electrons is mostly contained by the sample, but on a tilted surface, the plume is partially exposed and more electrons are emitted. By scanning the sample and detecting the secondary electrons, an image displaying the tilt of the surface is created.

FTIR stands for Fourier transform infrared, in which IR radiation is passed through a sample resulting in a spectrum after partial absorbance of radiation by the sample and partial transmission of the radiation through the sample. No two unique molecular structures produce the same infrared spectrum that makes infrared spectroscopy useful for several types of analysis. It is a technique for quantitative analysis to identify the amount of components of unknown materials and determine the quality or consistency of a sample.

\section{Measurements and analyses}

Due to the variation in reactor design and operation conditions adopted by researchers, uniformity in data reporting is required to compare the results among different systems The performance of EBCR can be determined by the parameters such as voltage, power, power density (reactor), power density (anode/cathode), volumetric power density (reactor), volumetric power density (anode/cathode), current density (reactor), current density (anode/cathode), volumetric current density (anode/cathode), volumetric current density (reactor). The cell voltage, current and resistance were monitored every $1 \mathrm{~h}$ using a digital multimeter (Aplab VC97). The conductivity and total dissolved solids were measured using water quality analyzer kit (ELICO WQ Analyzer). The $\mathrm{pH}$ was measured with a benchtop $\mathrm{pH}$ meter (Hanna Instruments). Using the titrimetric method, the total hardness and
Table 1 Characteristics of waste water used in the study

\begin{tabular}{ll}
\hline Parameters & Values \\
\hline BOD & $160 \mathrm{mg} / \mathrm{l}$ \\
Conductivity & $2 \mathrm{mS} / \mathrm{cm}$ \\
Alkakinity & $200 \mathrm{mg} / \mathrm{l}$ \\
$\mathrm{pH}$ & 7 \\
\hline
\end{tabular}

Table 2 Characteristics of seawater samples

\begin{tabular}{lll}
\hline Parameter & $\begin{array}{l}\text { Seawater from Nagapati- } \\
\text { nam coast (Sample I) }\end{array}$ & $\begin{array}{l}\text { Calicut } \\
\text { coast (Sam- } \\
\text { ple II) }\end{array}$ \\
\hline Conductivity (mS/cm) & 50 & 50.5 \\
TDS (ppt) & 31 & 32.32 \\
Hardness (mg/l) & 3000 & 3300 \\
Chloride (mg/l) & 18,744 & 20,022 \\
pH & 7.35 & 7.47 \\
\hline
\end{tabular}

chloride were determined (APHA standard methods). Current density (reactor), power density (reactor) and power density (anode/cathode) were calculated based on the observed values of current and voltage. The Biochemical Oxygen Demand (COD) of wastewater and anolyte (after and before changing) was measured using analytical method.

\section{Results and discussion}

\section{Performance of EBCR}

The wastewater from the influent to the aeration basin of Karunya Sewage Treatment Plant was used as a substrate in anode chambers of two identical EBCRs. The seawater samples taken from Nagapatinam coast, Tamil Nadu, and Calicut coast, Kerala, were filled in the middle chamber for treatment. The characteristics of wastewater and seawater samples are given in Tables 1 and 2. Both reactors were operated for almost the same lengths of time (140 h). PBS was used as catholyte in the first reactor while acidic water of $\mathrm{pH} 1$ was used as catholyte in the second reactor.

In the first reactor with PBS as catholyte, there was a maximum current generation of $0.37 \mathrm{~mA}$ and voltage production of $460 \mathrm{mV}$. The maximum current density and power density obtained were $109.6 \mathrm{~mA} / \mathrm{m}^{3}$ and $50.37 \mathrm{~mW} /$ $\mathrm{m}^{3}$, respectively. In the other reactor which was operated with acidic water as catholyte, there were better current generation and voltage generation. The maximum current and voltage obtained were $1 \mathrm{~mA}$ and $850 \mathrm{mV}$. The power 
Table 3 Performance of EBCR during cycles

\begin{tabular}{llll}
\hline & Parameters & Cycle I & Cycle II \\
\hline 1 & Current & $0.37 \mathrm{~mA}$ & $1 \mathrm{~mA}$ \\
2 & Voltage & $460 \mathrm{mV}$ & $850 \mathrm{mV}$ \\
3 & Power & $0.17 \mathrm{~mW}$ & $0.85 \mathrm{~mW}$ \\
4 & Power density (reactor) & $0.83 \mathrm{~mW} / \mathrm{m}^{2}$ & $4.19 \mathrm{~mW} / \mathrm{m}^{2}$ \\
5 & Power density (anode/cathode) & $7.5 \mathrm{~mW} / \mathrm{m}^{2}$ & $37.7 \mathrm{~mW} / \mathrm{m}^{2}$ \\
6 & Volumetric power density (reactor) & $1.86 \mathrm{~mW} / \mathrm{m}^{3}$ & $9.32 \mathrm{~mW} / \mathrm{m}^{3}$ \\
7 & Volumetric power density (anode/cathode) & $50.37 \mathrm{~mW} / \mathrm{m}^{3}$ & $251.8 \mathrm{~mW} / \mathrm{m}^{3}$ \\
8 & Current density (reactor) & $1.82 \mathrm{~mA} / \mathrm{m}^{2}$ & $4.9 \mathrm{~mA} / \mathrm{m}^{2}$ \\
9 & Current density (anode/cathode) & $16.44 \mathrm{~mA} / \mathrm{m}^{2}$ & $44.4 \mathrm{~mA} / \mathrm{m}^{2}$ \\
10 & Volumetric current density (anode/cathode) & $109.6 \mathrm{~mA} / \mathrm{m}^{3}$ & $296.29 \mathrm{~mA} / \mathrm{m}^{3}$ \\
11 & Volumetric current density (reactor) & $4.06 \mathrm{~mA} / \mathrm{m}^{3}$ & $10.97 \mathrm{~mA} / \mathrm{m}^{3}$ \\
\hline
\end{tabular}

Table 4 Performance of EBCR in removing salts from Sample I

\begin{tabular}{lllll}
\hline S. no. & Parameters & Initial & Final & $\begin{array}{l}\text { Percent- } \\
\text { age reduc- } \\
\text { tion }\end{array}$ \\
\hline 1 & EC (mS/cm) & 50.50 & 20 & 60.3 \\
2 & TDS (ppt) & 32.32 & 12.8 & 60.3 \\
3 & Hardness (mg/l) & 3300 & 0 & 100 \\
4 & Chloride (mg/l) & 20,022 & 9230 & 53 \\
\hline
\end{tabular}

Table 5 Performance of EBCR in removing salts from Sample II

\begin{tabular}{lllll}
\hline S. no. & Parameters & Initial & Final & $\begin{array}{l}\text { Percent- } \\
\text { age reduc- } \\
\text { tion }\end{array}$ \\
\hline 1 & EC (mS/cm) & 50.36 & 25.01 & 50.33 \\
2 & TDS (ppt) & 32.23 & 16.00 & 50.35 \\
3 & Hardness (mg/l) & 3000 & 0 & 100 \\
4 & Chloride (mg/l) & 18,744 & 10,372 & 44.6 \\
\hline
\end{tabular}

Fig. 3 Voltage versus reduction percentage in EC density and current density obtained were $251.8 \mathrm{~mW} / \mathrm{m}^{3}$ and $296.29 \mathrm{~mA} / \mathrm{m}^{3}$ (Tables 3, 4 and 5).

\section{Desalination}

There was 50\% and 60\% removal of EC in the first and second reactors, respectively. It was observed that there was $100 \%$ removal of hardness in both reactors. Graphs which correlate the current, voltage and percentage reduction in $\mathrm{EC}$ are given (Figs. 3, 4 and 5). It clearly shows that in the 100th hour there is a drop in current and voltage, whereas the percentage reduction in EC does not change after that hour. The graph correlating power density and current density show that there is a drop at 100th hour (Fig. 5).

\section{BOD removal}

The maximum reduction in $\mathrm{BOD}_{5}$ was found to be $38 \%$ in the first reactor, and in the other one, there was $45 \%$ removal. It indicates that waste water is being treated and organic matter is getting degraded in the anode chamber (Table 6).

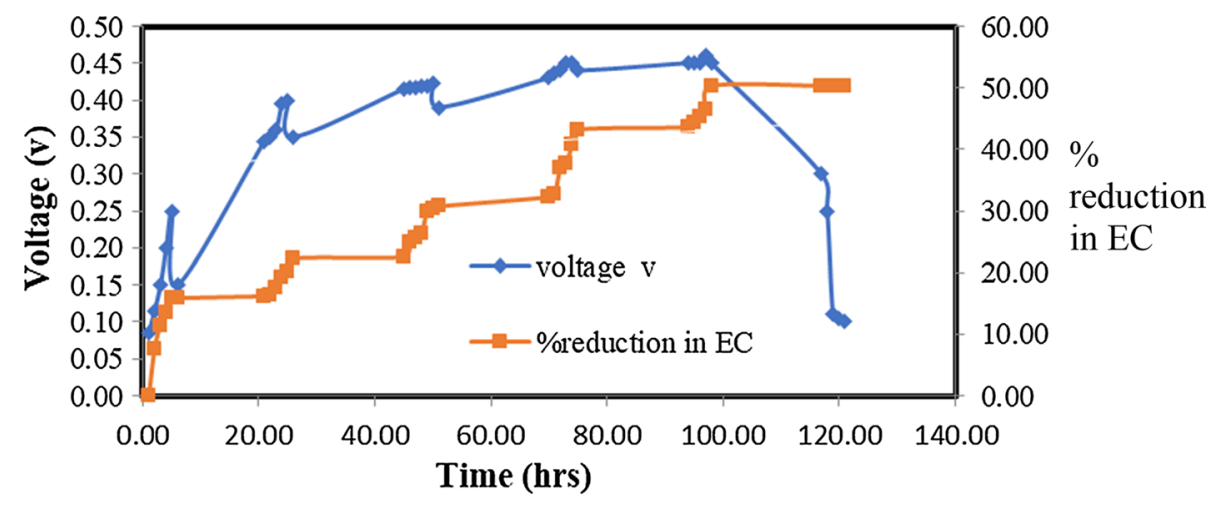


Fig. 4 Current versus percentage reduction in EC

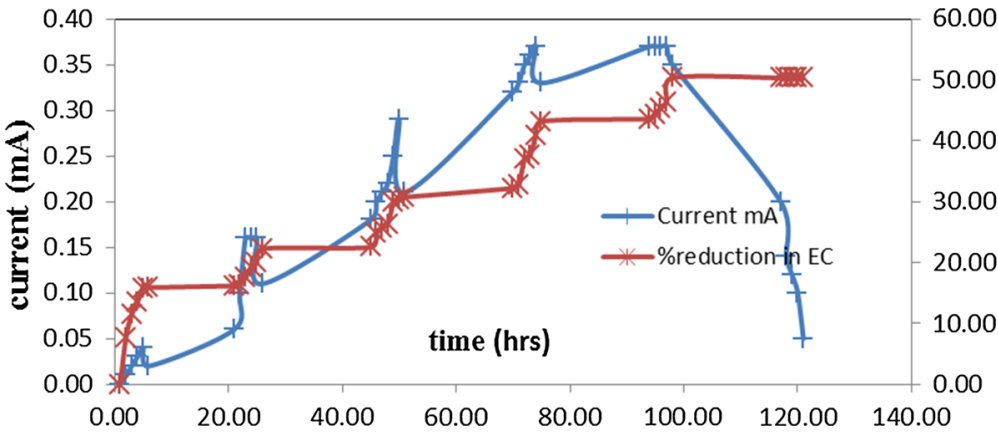

\section{Effects of desalination on EBCR performance}

\section{Effect on conductivity}

The conductivity graph of anolyte and catholyte is shown in Fig. 6 . The increase in conductivity in anode chamber is due to the addition of chloride ion into the anode chamber from middle chamber. The cathode conductivity gradually decreases due to the formation of pure water in the cathode chamber.

\section{Effect on $\mathrm{pH}$}

The $\mathrm{pH}$ in the anode chamber gradually decreases while that in cathode chamber increases gradually. The $\mathrm{pH}$ of anode chamber goes below neutral range and becomes acidic, and that of cathode chamber goes above neutral range and becomes alkaline. The decrease in $\mathrm{pH}$ in anode chamber is due to the microbial activity of bacteria and due to the accumulation of protons. The increase in $\mathrm{pH}$ in the cathode chamber is due to the reduction in protons due to the formation of water. Neutral $\mathrm{pH}$ in anode and highly acidic $\mathrm{pH}$ in cathode are recommended. Using acidic water in the cathode chamber is preferable to maintain this condition.

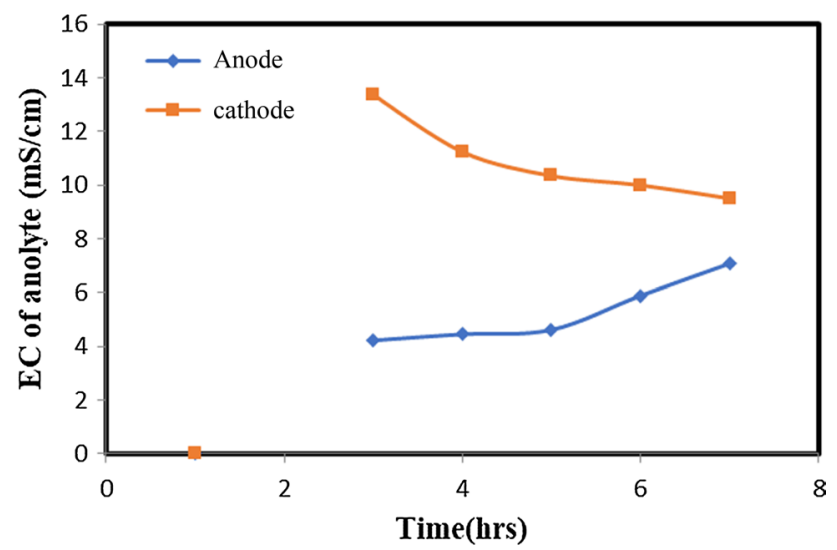

Fig. 6 Conductivity variation in anolyte and catholyte

\section{Characterization studies of wastewater}

FTIR spectral analysis was carried out to understand the unknown materials, quality and the amount of components of waste water. It also shows the structural changes, before and after the treatment process. Mostly the domestic waste water contains soap as a major contaminant. The IR spectrum of waste water contains the following frequency mainly due to organic pollutant from soap and detergents. The peak at $1647.21 \mathrm{~cm}^{-1}$ corresponds to alkene compounds $-\mathrm{C}=\mathrm{C}-$ maybe from oleic acid or linoleic acid salts.

$$
\begin{aligned}
& \mathrm{CH}_{3}-\left(\mathrm{CH}_{2}\right)_{7}-\mathrm{CH}=\mathrm{CH}-\left(\mathrm{CH}_{2}\right)_{7} \mathrm{COOH} \text { or } \\
& \mathrm{CH}_{3}\left(\mathrm{CH}_{2}\right)_{3}-\left(\mathrm{CH}_{2}-\mathrm{CH}=\mathrm{CH}\right)_{2}-\left(\mathrm{CH}_{2}\right)_{7}-\mathrm{COOH} \text { (Linoleic acid) }
\end{aligned}
$$

The peak at $1550 \mathrm{~cm}^{-1}$ belongs to amino acid (N-O asymmetric stretching). The peak at $1419.61 \mathrm{~cm}^{-1}$ shows 
antisymmetrical stretching due to $\mathrm{COO}-$ which is from soap. The peaks at $1022 \mathrm{~cm}^{-1}$ are due to aliphatic amines.

\section{Membrane fouling}

\section{Biofouling}

Biofouling of ion exchange membranes, especially in the AEM that was in contact with the anolyte, was expected. Through visual inspection, it was observed that the surface of the AEM turned black and was covered with a fungi-like deposit. The analysis of SEM images provided more detailed information about the conditions of the membrane surface and clearly showed the difference between a raw membrane (unused) and the fouled membranes. The raw membranes of both the AEM and the CEM exhibited a slightly cracked surface which may be due to mixture of bacteria and fungi. On the AEM facing the anode, both microorganisms and salt deposit were observed which confirmed the separation of $\mathrm{Cl}^{-}$ions from middle chamber. A mud-shaped structure was observed on the membrane. Although microbial analysis was not performed, spherical-shaped microbial morphology was noted.

\section{Inorganic scaling}

The scaling on ion exchange membranes is mainly caused by the precipitation of various inorganic compounds such as sodium chloride, calcium carbonate and magnesium hydroxide. It was observed that a layer of whitish crystals and deposits is formed on the AEM and CEM facing middle chamber. Higher concentrations of sodium, calcium and magnesium ions in seawater are the major scaling ions. During the operation, both sodium ions migrated across the CEM into the cathode chamber as a result of the electricity generation. The scaling on the AEM (the side facing seawater) was less serious than that of the CEM. The SEM image of CEM facing cathode side shows the formation of sodium phosphate which indicates the movement of sodium ion. The salts were unevenly distributed on the membrane.

\section{Crystal structure of membrane}

\section{AEM facing anode chamber}

Figures $4,5,6,7,8,9,10,11$ and 12 show the crystalline structure of AEM facing anode chamber. The strongest peaks are at $29.3^{\circ}, 31.70^{\circ}$ and $32.30^{\circ}$. The crystallite size of the AEM is $34.5 \mathrm{~nm}$.

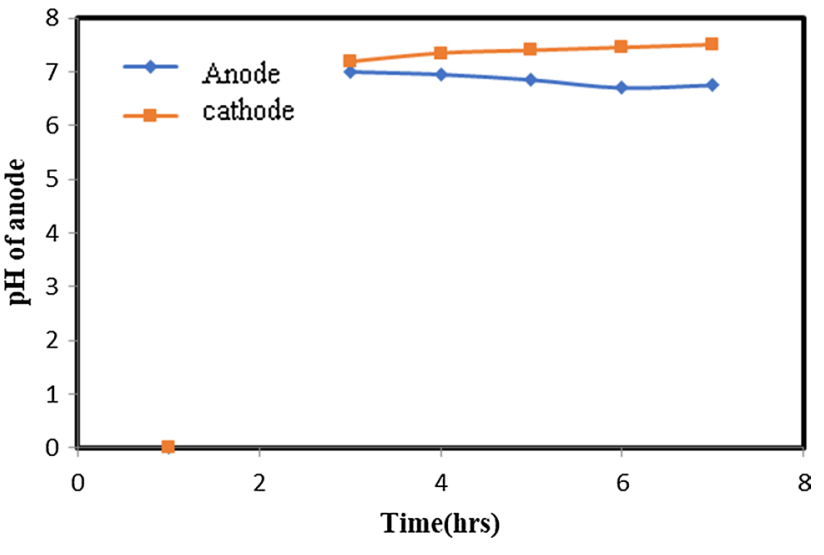

Fig. 7 pH Variation in anolyte and catholyte

\section{AEM facing middle chamber}

The above figure shows the crystalline structure of AEM facing middle chamber. The intense diffraction patterns were observed at $29.6^{\circ}$ and $47.6^{\circ}$ which correspond to $\mathrm{NaCl}$ crystalline (JCPDS 83-1728S). So it clearly indicated that sodium chloride was deposited on the AEM facing the middle chamber. It also infers that other impurities are not present in this. The crystallite size of sodium chloride is $39.0 \mathrm{~nm}$.

\section{CEM facing middle chamber}

The above figure shows the crystalline structure of CEM facing middle chamber. The intense diffraction patterns were at $20.5^{\circ}$ and $31.2^{\circ}$ which correspond to $\mathrm{CaCl}_{2}$ crystalline (JCPDS 49-1092). So it clearly indicated that calcium chloride is deposited on the CEM facing the cathode side and it is of good crystalline nature. It also infers that other impurities are not present in this. The crystallite size of calcium corresponds to $40.28 \mathrm{~nm}$.

\section{CEM facing cathode chamber}

The above figure shows the crystalline structure of CEM facing cathode chamber. The intense diffraction patterns are at $30.9^{\circ}$ and $25.2^{\circ}$ which correspond to $\mathrm{NaPO}_{3}$ crystalline (JCPDS 11-0650). So it clearly indicates that sodium phosphate is formed on the CEM facing the cathode side and it is of good crystalline nature. It is also inferred that the other impurities are not present in this. It suggests that the scaling has occurred when the sodium migrated across the CEM and bonded to the phosphate. The crystal structure which is formed is monoclinic, and crystallite size is $10.6 \mathrm{~nm}$. 


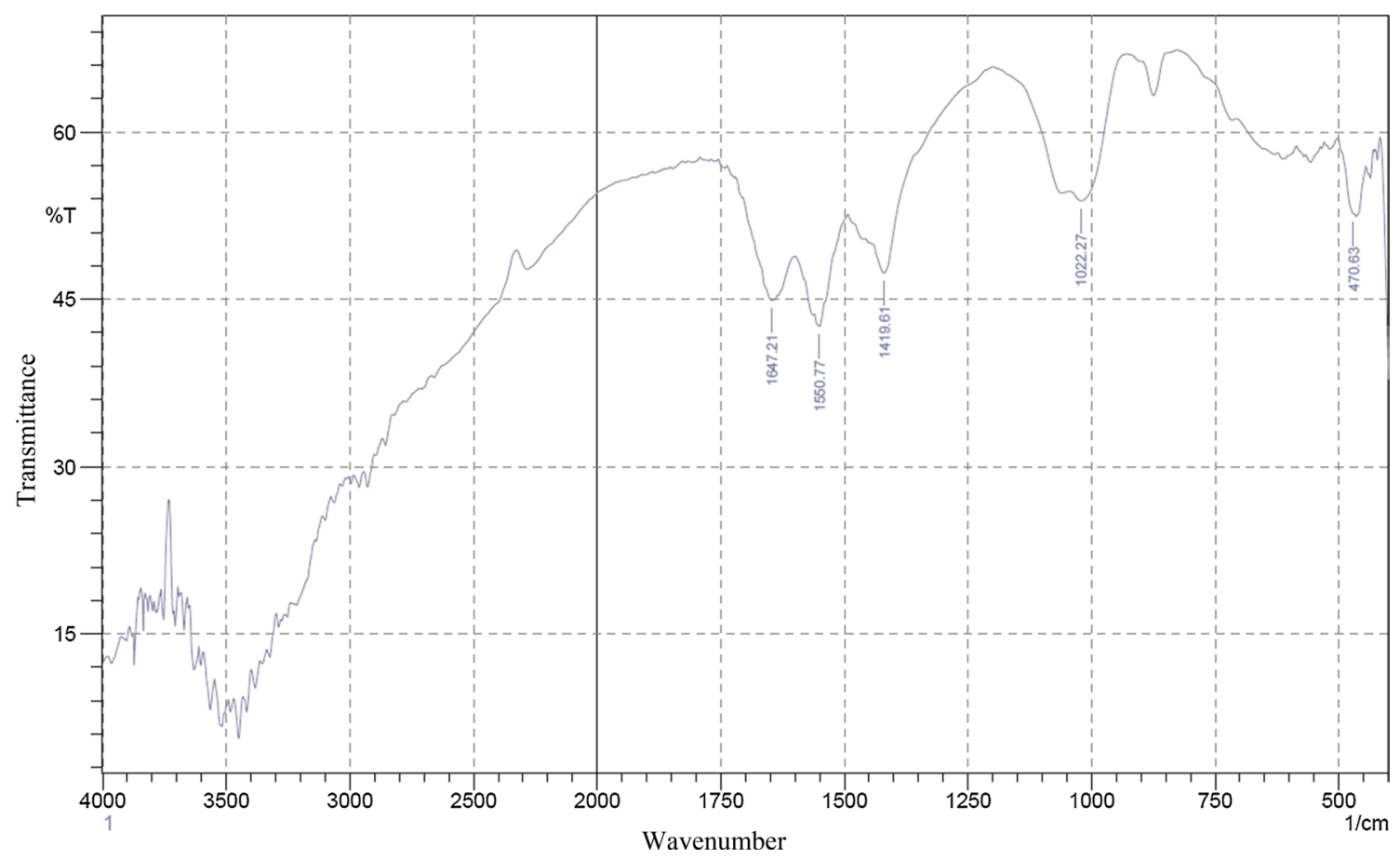

Fig. 8 FTIR of domestic waste water

Fig. 9 SEM image of ion exchange membrane: a raw AEM membrane and $\mathbf{b}$ AEM facing anode chamber after treatment

Fig. 10 a SEM image of raw CEM and $\mathbf{b}$ used CEM facing cathode chamber
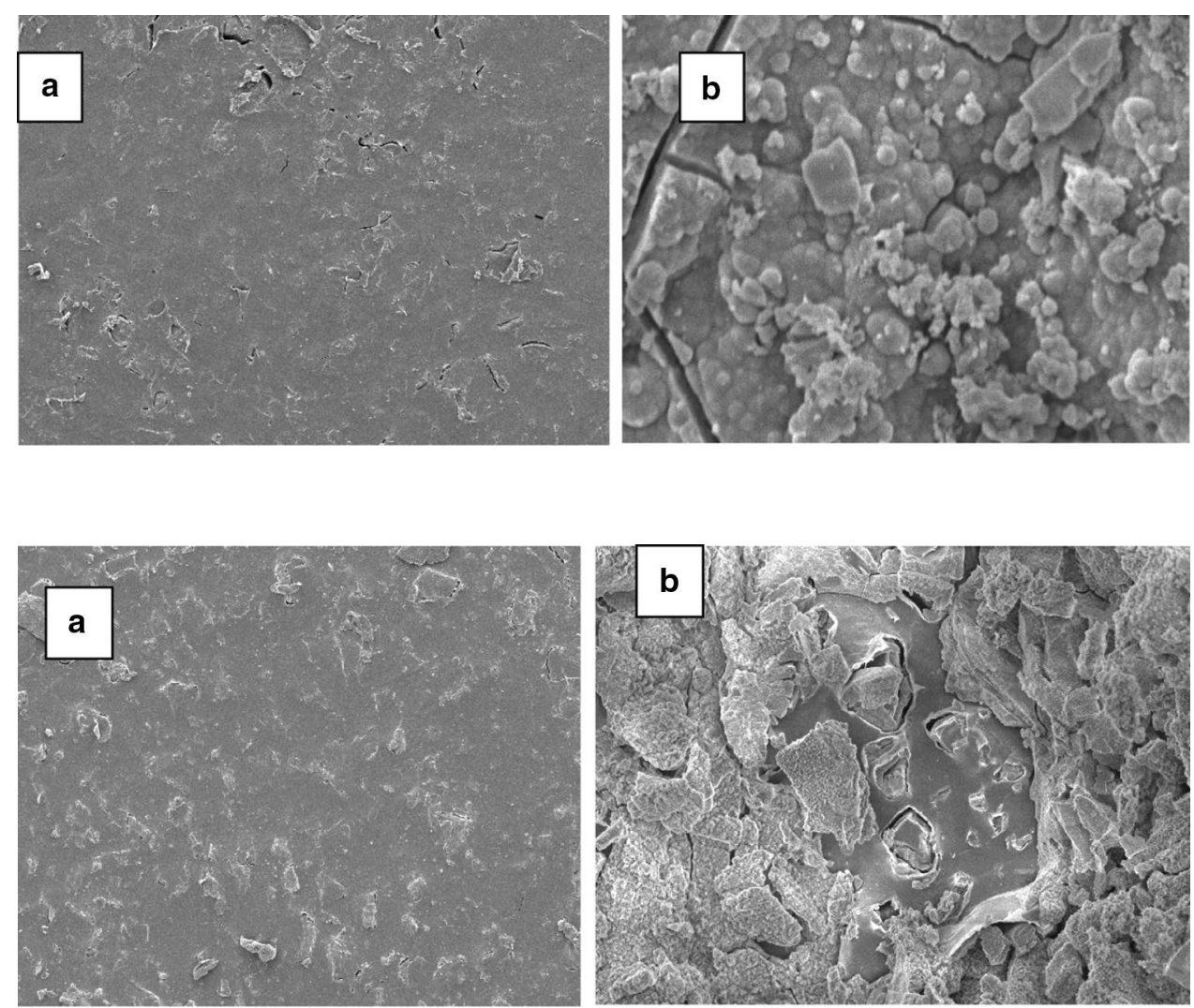
Fig. 11 a and $\mathbf{b}$ SEM images of used AEM facing seawater
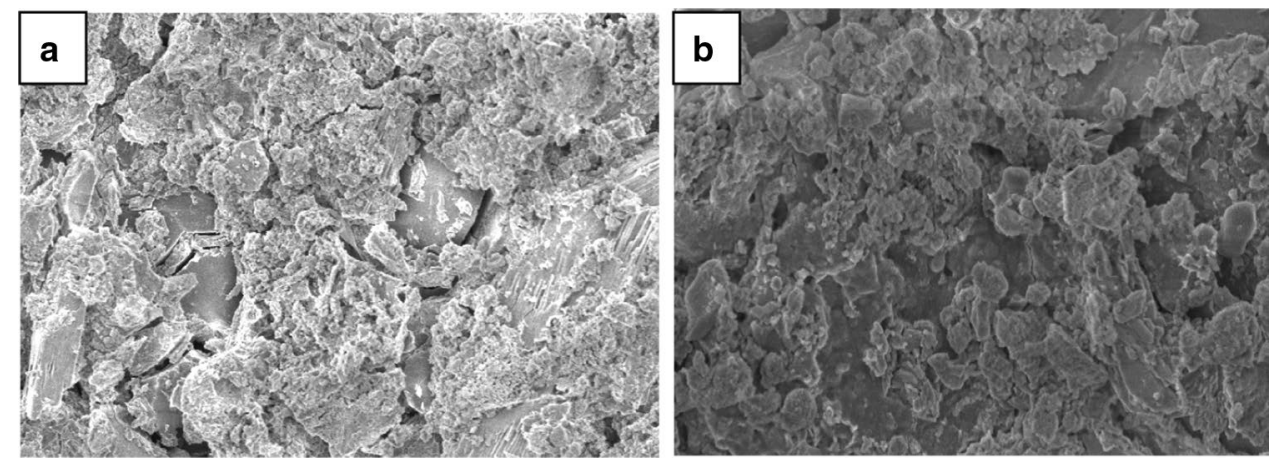

AA

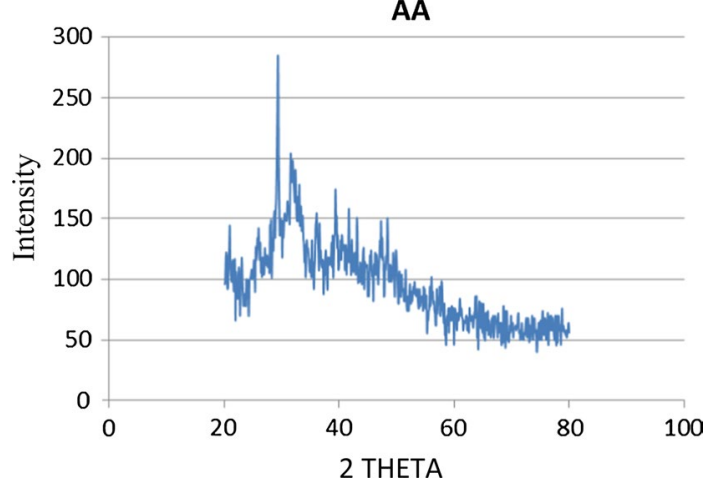

Fig. 12 XRD pattern of AEM facing anode chamber

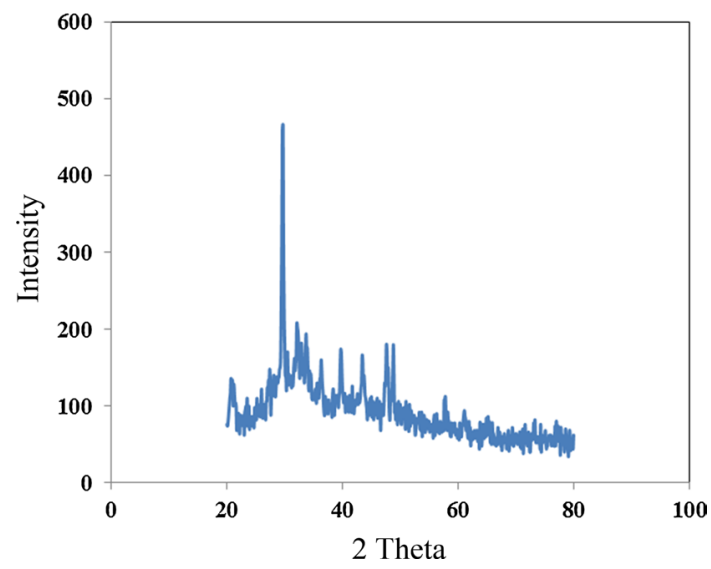

Fig. 13 XRD pattern of AEM facing middle chamber

\section{Conclusion}

This study demonstrated that EBCR can be used for desalination along with other advantages like energy production and waste water treatment. The second reactor with acidic water as catholyte proved to be more efficient. It was noted that there was $100 \%$ removal of hardness during the treatment using EBCR. There was current generation of $1 \mathrm{~mA}$

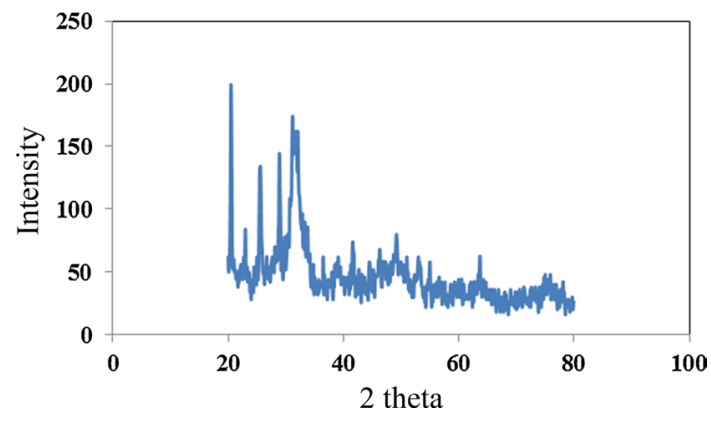

Fig. 14 XRD pattern of CEM facing middle chamber

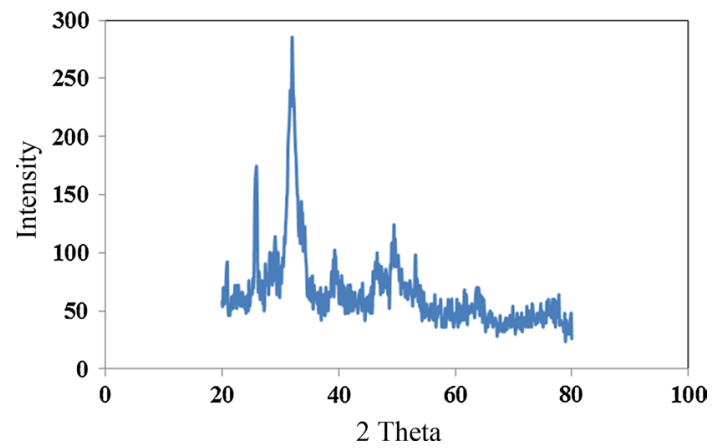

Fig. 15 XRD pattern of CEM facing cathode chamber

with voltage of $850 \mathrm{mV}$. About $60 \%$ of EC and $40 \%$ of BOD were removed. A power density of $251.8 \mathrm{~mW} / \mathrm{m}^{2}$ and current density of $296.29 \mathrm{~mA} / \mathrm{m}^{2}$ were also obtained. From this, it can be concluded that the EBCR is the most energy-efficient alternative for desalination as well as for the waste water treatment (Figs. 13, 14 and 15).

Open Access This article is distributed under the terms of the Creative Commons Attribution 4.0 International License (http://creativeco mmons.org/licenses/by/4.0/), which permits unrestricted use, distribution, and reproduction in any medium, provided you give appropriate credit to the original author(s) and the source, provide a link to the Creative Commons license, and indicate if changes were made. 


\section{References}

Brastad KS, He Z (2013) Water softening using microbial desalination cell technology. Desalination 309:32-37

Cao X, Huang X, Liang P, Xiao K, Zhou Y, Zhang X, Logan BE (2009) A new method for water desalination using microbial desalination cells. Environ Sci Technol 43(18):7148-7152

Carter NT (2013) Desalination and membrane technologies: federal research and adoption issues. Congressional Research Service, Washington D.C.

Elimelech M, Phillip WA (2011) The future of seawater desalination: energy, technology, and the environment. Science 333:712-717

Garud RM, Kore SV, Kore VS, Kulkarni GS (2011) A short review on process and applications of reverse osmosis. Univers J Environ Res Technol 1(3):233-238

Glass N (2010) The water crisis in Yemen: causes, consequences and solutions. Glob Major E-J 1(1):17-30

Greenlee LF, Lawler DF, Freeman BD, Marrot B, Moulin P (2009) Reverse osmosis desalination: water sources, technology, and today's challenges. Water Res 43:2317-2348

IREA (2012) Water desalination using renewable energy. IEA-ETSAP and IRENA@ Technology Brief I12-March 2012

Kim Y, Logan BE (2011) Series assembly of microbial desalination cells containing stacked electrodialysis cells for partial or complete seawater desalination. Environ Sci Technol 45(13):5840 5845. https://doi.org/10.1021/es200584q

Kim Y, Logan BE (2013) Microbial desalination cells for energy production and desalination. Desalination 308:122-130

Kokabian B, Gude VG (2012) Algal microbial desalination cell for clean energy, water and biomass production. Mississipi State University, Starkville

Lattemann S, Kennedy MD, Schippers JC, Amy G (2010) Global desalination situation. In: Escobar IC, Schafer AI (eds) Sustainable water for the future: water recycling versus desalination. Elsevier, Amsterdam

Luo HP, Jenkins PE, Ren ZY (2010) Concurrent desalination and hydrogen generation using microbial electrolysis and desalination cells. Environ Sci Technol 45(1):340-344

Luo H, Xu P, Ren Z (2012a) Long-term performance and characterization of microbial desalination cells in treating domestic wastewater. Bioresour Technol 120:187-193

Luo H, Xu P, Roane TM, Jenkins PE, Ren Z (2012b) Microbial desalination cells for improved performance in wastewater treatment, electricity production, and desalination. Bioresour Technol 105:60-66
Marshall S (2011) The water crisis in Kenya: causes, effects and solutions. Glob Majo E-J 2(1):31-45

Mehanna M, Logan BE (2010) Microbial desalination cell for simultaneous water desalination and energy production. Global water program

Mehanna M, Saito T, Yan J, Hickner M, Cao X, Huang X, Logan BE (2010) Using microbial desalination cells to reduce water salinity prior to reverse osmosis. Energy Environ Sci 3(8):1114-1120

Ping Q, Cohen B, Dosoretz C, He Z (2013) Long-term investigation of fouling of cation and anion exchange membranes in microbial desalination cells. Desalination 325:48-55

Prakash A, Sharma M, Chourey J (2013) Water in India: situation and prospects. UNICEF, FAO and Saci Waters

Qu Y, Feng Y, Wang X, Liu J, Lv J, He W, Logan BE (2012) Simultaneous water desalination and electricity generation in a microbial desalination cell with electrolyte recirculation for $\mathrm{pH}$ control. Bioresour Technol 106:89-94

Qu Y, Feng Y, Liu J, He W, Shi X, Yang Q, Lv J, Logan BE (2013) Salt removal using multiple microbial desalination cells under continuous flow conditions. Desalination 317:17-22

Ren J, Luo H (2010) Microbial electrochemical cell for simultaneous water desalination, energy production, and wastewater treatment. Present to joint U.S.-China workshop

Sabat RR, Swain MK, Garnaik JJ, Sarangi S (2013) Utilization of waste water and production of electricity using non mediated microbial fuel cell. IOSR J Electr Electron Eng (IOSR-JEEE) 4(2):47-51

Semiat R (2008) Energy issues in desalination processes. Environ Sci Technol 42:8193-8202

Tänzler D, Ruettinger L, Ziegenhagen K, Murthy G (2011) Water, crisis and climate change in India: a policy brief. adelphi, Berlin/ Tirupati

United Nations Department of Economics and Social Affairs (2003) International decade for action 'Water for life 2005-2015'. https ://www.un.org/development/desa/en

World Bank (2012) Renewable energy desalination. 2012 International Bank for Reconstruction and Development/The World Bank 1818 H Street NW, Washington DC 20433

Zhang Y (2012) Energy recovery from waste streams with microbial fuel cell (MFC)-based technologies. Technical University of Denmark, Lyngby

Zhang B, He Z (2012) Energy production, use and saving in a bioelectrochemical desalination system. RSC Adv 2(28):10673-10679

Publisher's Note Springer Nature remains neutral with regard to jurisdictional claims in published maps and institutional affiliations. 